\title{
China-Angola aid relations: strategic cooperation for development?
}

\begin{abstract}
Carine Kiala*
Until recently the international donor community has predominantly consisted of members of the Development Assistance Committee (DAC) of the Organisation for Economic Cooperation and Development (OECD). However, China does not entirely conform to the OECD on matters related to aid; it is also not a member of the DAC. Hence, the data on China's aid, as well as its focus, purpose, terms and conditions are controversial because they are not clear. Furthermore, on the receiving end, Angola is equally reticent to discuss its management of state funds. The uncertainties and the opaque nature of diplomatic relations are compounded by a perceived overlap and ambiguity between aid and investment. The objective of the study is to examine China-Angola aid relations and provide critical judgement of it characterising strategic cooperation for the development of Angola.
\end{abstract}

Keywords: China; Angola; Africa; development aid

\section{Introduction}

Angola increasingly finds itself at the centre of debate surrounding Chinese activity in Africa. Although Angola is the continent's largest oil exporting country, poverty remains rampant. In its relations with China, Angola seeks strategic cooperation for its development. It is an innovative model that embodies China's notion of 'win-win' cooperation, where an oil-backed credit line is used to finance the reconstruction and development of infrastructure.

The literature on China-Africa relations has increased rapidly in recent years. However, it primarily focuses on Chinese activity in African countries as opposed to the benefits for the respective countries. Although there is agreement on the intensification of China's engagement of African countries, there also remains debate over its motivations. This article examines how China is redefining the parameters of aid, setting a precedent through its strategic cooperation towards socio-economic development in Angola. ${ }^{1}$ The article introduces China's emergence in the donor community and how it is redefining the parameters of aid in Africa, followed by discussion quantifying Chinese aid to Angola and an outline of the various themes in that aid. Finally, the article critically examines the risks of the Chinese credit line for Angola and offers policy recommendations.

\section{China redefines the parameters of aid in Africa}

China has come a long way, from a traditional donor recipient to a significant creditor in the group of 'new' donors active in Africa. However, China's involvement with the Organisation for Economic Cooperation and Development (OECD)

\footnotetext{
*Email: ckiala@yahoo.com
} 
remains strictly as an aid recipient. China is not a part of the OECD's Development Assistance Committee (DAC) and has often followed a doctrine that is different (perhaps even contradictory) to that of the West, essentially reflecting its own principles to achieve poverty alleviation, as noted by Brautigam. ${ }^{2}$

China's earliest involvement in Africa dates back to the colonial era when it offered military assistance to liberation movements during their struggle for independence. Although this form of aid to Angola still continues to date, ${ }^{3}$ China's aid packages to African countries have diversified over the years. Accordingly, medical cooperation is one of the most important segments of China's official development assistance: in 1963 Beijing sent its first medical team to Algeria. ${ }^{4}$ As China's diplomatic relations with African countries grew over the years as more African states chose in favour of the 'One China' policy, ${ }^{5}$ China's relations with the continent have become more multilateral in nature. This is evident in the launch and remarkable growth of the Forum on China-Africa Cooperation (FOCAC). Since that launch in 2000, Sino-African relations have displayed an accelerated scale of engagement.

FOCAC has held four ministerial meetings, in 2000, 2003, 2006 and 2009. Their respective action plans detail the commitment of China and African member states to cooperation in the political, economic and social development realms. ${ }^{6}$ At the opening of the FOCAC summit in November 2006, Chinese President Hu Jintao announced eight policy measures to strengthen cooperation between China and Africa, which are intended to capture the essence and diversity of Beijing's aid to Africa. ${ }^{7}$ Six months later, in May 2007, the African Development Bank's (AfDB) annual general meeting was held in Shanghai. The meeting was attended by 50 African heads of state, demonstrating Africa's enthusiasm to branch into new frontiers of a shifting donor community. At the 2009 FOCAC ministerial meeting, held in Egypt, Africa was just as well represented.

China has become a major development partner across Africa, but its intentions remain a subject of much debate. Critics claim that mounting Chinese aid to Africa will result in unsustainable levels of debt, adversely affect governance and negatively impact on the ecological environment. Nevertheless, African countries recognise an opportunity in China and their engagement demonstrates new alignments in world affairs.

For a developing country, China has gained a remarkable foothold in international affairs. Its political influence is long-standing, especially since 1971 when it became a permanent member of the United Nations Security Council. Although China is technically a developing country, for many years it has been treated as a developed country because of its sheer size and impact on the world economy and political stage. Its economic influence has gained much momentum more recently from the manner in which it weathered the global financial crisis beginning in 2008 .

Since the onset of its double-digit growth rate in the 1980s, China has experienced an unprecedented run of economic development that today makes it the world's second largest economy - after the United States. Most astounding, China has lifted 400 million of its own population (now estimated at 1.4 billion) out of poverty in the last 20 years. In the same period, Africa was the only developing region of the world whose socio-economic indicators regressed. ${ }^{8}$ China identifies in its own past challenges that resonate with the difficulties experienced in many African countries today. Redefining its relations with African countries is thus opportune, for it comes 
at a time when African leaders are eager to diversify their international relations and development partners.

China's aid to African countries consists of aid in kind, zero interest loans and concessional loans, which all resemble, for the most part, the OECD's aid activities. Chinese aid includes cooperative joint-venture funds for aid projects, cooperation in science and technology and cooperation in social development - education, training, medical support and healthcare. Although the agreements differ according to bilateral negotiations, the criteria for Chinese aid remain relatively the same. However, China's recent entry to the donor community with apparently no imposed conditionalities has prompted much controversy.

Unlike the OECD, which provides debt relief only to highly indebted poor countries (HIPCs), China provides debt relief to least developed countries (LDCs) as well. The volumes may differ, but China's criteria for debt relief is more relaxed. LDCs, Angola among them, are countries that the UN considers to have low income, weak human resources and are economically vulnerable. The variables used to measure the socio-economic indicators include health, nutrition, agricultural production, instability in the export of goods and services, among others. HIPCs, on the other hand, are a group of 40 LDCs identified by the World Bank and the International Monetary Fund (IMF) on the basis of their high levels of poverty and international debt.

Chinese concessional loans are provided by its Export-Import Bank (Exim Bank), and are accompanied by an interest subsidy from the Ministry of Commerce (MOFCOM). Although the size of some loans to Angola have been publicised, the total volume of aid has never been revealed and the terms of the agreements remain undisclosed. Generally, China's concessional loans must be serviced over a 10-15 year period, at a $2 \%$ interest rate. No grace period is included and the Chinese yuan is pegged as the debt currency, not the US dollar. ${ }^{9}$

In May 2007, China's Exim Bank and the World Bank signed a memorandum of understanding (MOU) to improve their cooperation in development issues in Africa. The World Bank's Vice President for Asia, Jim Adams, insisted that including China in the global donor system would be imperative to ensuring transparency and debt sustainability in the international donor community. ${ }^{10}$ Even so, analysts suspect this move was purely the World Bank's attempt at avoiding competition with China. After all, Chinese banks are already cementing relations with the largest pan-African bank. After the AfDB's meeting in Shanghai, the bank signed MOUs with China's Exim Bank in May 2008 and with China's Development Bank (CDB) in September of that year. Both agreements demonstrate a shared interest in collaborating in the co-financing and coordination of development projects in Africa. ${ }^{11}$

The continual disbursement of aid raises questions about its effectiveness and its accumulation. The OECD, through the Bretton Woods institutions, had until recently remained unchallenged on issues surrounding aid. Now China's entry to the scene is redefining the parameters of aid. In relation to Angola it appears timely for both parties. During the early 1990s China began its shift from being a petroleum exporting country to, by 2009 , being a net importer of petroleum - consuming 5.46 million barrels a day. ${ }^{12}$ Angola, as of 2009, has stepped up as the largest oil producing country in Africa, surpassing Nigeria where insurgents continue to destabilise the oil extraction industry. ${ }^{13}$ In the new millennium, post-conflict Angola embarked on an ambitious plan of national construction and development and 
sought financial assistance from the donor community. However, Luanda would not submit to the International Monetary Fund's suggested poverty reduction strategy plans (PRSPs) and staff-monitored programmes (SMPs), which paved the way for China's entry as a donor. Five years since China's US\$ 2 billion credit line was issued in 2004, Angola has recorded impressive growth rates. The country is eager to become a powerhouse in the southern African region. It hosted its first OPEC meeting in January 2009, as well as the African Cup of Nations football tournament in January 2010.

\section{Quantifying Chinese aid to Angola}

In 2002, China's Exim Bank and the China Construction Bank (CCB) provided US\$ 145 million towards Angola's reconstruction. The funding poured into rehabilitating a 444 kilometre railway through Luanda and expanding the electrical systems in Luanda, Lubango, Namibe and Tombwa. ${ }^{14}$ By 21 March 2004 the relations intensified further when Exim Bank extended a US\$ 2 billion oil-backed credit line to Angola. Compared to the IMF, the terms for the credit were viewed to be less invasive of domestic policy and more business-based. As a precondition to the loans, which were all earmarked for Angola's reconstruction and development projects, $70 \%$ of the projects would be contracted to Chinese enterprises. Also, Angola agreed to provide China with 10,000 barrels of oil per day from its oil exports. The loans were disbursed in two phases of just over US\$ 1 billion each, payable over a 12-year period at an interest rate of $1.5 \%$. The first half of the loan was released expeditiously, by December 2004. Both countries proceeded with negotiations for further financial cooperation. Hence, in May 2007 Angola was credited with an additional US\$ 500 million after having exhausted nearly US\$ 837 million of the second phase funds. ${ }^{15}$ During Exim Bank President Li Ruogu's visit to Angola in September 2007, he announced that Exim Bank would provide an additional US\$ 2 billion loan to finance public investments. ${ }^{16}$

Angola's president José Eduardo dos Santos visited Beijing in December 2008 to reinforce bilateral agreements, amid the tumbling oil price at the height of the global economic crisis. A month after dos Santos' trip to China, Chinese Minister of Commerce Chen Deming visited Angola. During his stay Chen held separate meetings with Angola's Prime Minister Antonio Paulo Kassoma, Finance Minister José Pedro de Morais and Trade Minister Indalina Valente. ${ }^{17}$ By March 2009, China extended another US\$ 1 billion through the CDB to develop Angola's agricultural sector. Since extending the credit line by another US\$ 4 billion in September 2010, China's estimated cumulative credit line to Angola now stands at approximately US\$ 9.5 billion. In just five years, China's development assistance to Angola now surpasses the combined contributions of all DAC members. Accordingly, any reference to similar plans for rapidly and exponentially expanding aid relations has popularly been dubbed 'Angola Mode'.

Concurrent to its relations with the People's Republic of China (PRC), Angola has developed ties with the Hong Kong-based China International Fund (CIF), which is often associated with the PRC by default. It is worth mentioning that Angola has received significant lines of credit and loans from the CIF, as well, amounting to approximately US\$2.9 billion further funding. 


\section{The thematic focus of Chinese aid to Angola}

China's aid to Angola cuts across various sectors, as categorised in Table 1. Although concessional loans form a great part of China's development assistance to Angola, the section below explores the diverse themes that apply to Chinese aid.

Such basic data may be easily accessed from the Angolan Ministry of Finance, but further details on the projects are difficult to attain. Also, there is often uncertainty in distinguishing projects from one another and discerning their respective funding schemes. The projects examined below are not a complete account of all the Chinese aid projects in Angola, nonetheless they illustrate the type of aid provided and offer a basis of analysis. The information was collated from various media, as well as verified during field research in Angola.

\section{Public health and medical care}

Since the end of the war, Angola's government has been adamant that it must restore the country's medical care facilities and its public health system, which are both significant factors in the production and productivity of the country's human capital. The life expectancy at birth ranges between 38-45 years, based on varying sources. Malaria and typhoid are the main causes of death caused by illness: malaria alone kills an average of 14,000 people in Angola per year, ${ }^{18}$ and accounts for nearly $60 \%$ of hospital admissions for children under five, $35 \%$ of mortality in children in the same age group and $25 \%$ of maternal mortality. ${ }^{19}$ There are also frequent cholera outbreaks across the country, a result of poor sanitation and limited access to safe drinking water. Nearly half the population (47\%) is without access to improved water sources. Other illnesses that contribute significantly to the low mortality rate include African trypanosomiasis (sleeping sickness) and other water-borne diseases. According to official statistics, the HIV/AIDS infection rate is just $2.1 \%{ }^{20}$

The Chinese government has pledged aid towards medical care and improving Angola's healthcare system. Chinese enterprises have been upgrading existing medical facilities on behalf of the Ministry of Health. During the period 20062008, Sinohydro, for instance, embarked on a US\$ 148.7 million project to expand and renovate four regional hospitals around the country — in Benguela, Huambo,

Table 1. Composition of Exim Bank's loans to Angola

\begin{tabular}{|c|c|c|c|c|c|}
\hline \multirow[b]{2}{*}{ Sector } & \multicolumn{2}{|c|}{ 2004: Phase I } & \multicolumn{2}{|c|}{ 2004: Phase II } & \multirow{2}{*}{$\frac{2007}{\begin{array}{c}\text { US\$ } \\
\text { million }\end{array}}$} \\
\hline & $\begin{array}{l}\text { No. of } \\
\text { contracts }\end{array}$ & $\begin{array}{l}\text { US\$ } \\
\text { million }\end{array}$ & $\begin{array}{l}\text { No. of } \\
\text { contracts }\end{array}$ & $\begin{array}{l}\text { US\$ } \\
\text { million }\end{array}$ & \\
\hline Health & 9 & 206 & 1 & 43 & 159 \\
\hline Education & 8 & 217 & 3 & 229 & 145 \\
\hline Energy and water & 8 & 243 & 3 & 144 & 76 \\
\hline Agriculture \& fisheries & 3 & 149 & 4 & 320 & 41 \\
\hline Transport & 1 & 13 & $\ldots$ & $\ldots$ & $\ldots$ \\
\hline Social communications & 1 & 66 & 4 & 276 & 56 \\
\hline Public works & 1 & 211 & 2 & 89 & 65 \\
\hline Subtotal & 31 & 1105 & 17 & 1101 & 542 \\
\hline
\end{tabular}

Source: Campos I and A Vines Angola and China: A Pragmatic Partnership. London: Chatham House, 2008 , pp. 7-8. <http://www.chattamhouse.org.uk/publications/papers/view/-lid/603 > (accessed 16 November 2010). 
Lubango and Malange. ${ }^{21}$ In April 2007, Sinohydro also initiated the procurement of 86 ambulances for Angola's Ministry of Health with funding (US\$ 4.38 million) from the Exim Bank line of credit. Seven ambulances are in reserve, while the remaining 79 have been delivered across all 18 provinces. ${ }^{22}$

China funded the construction of Luanda's Central Hospital in Kilamba Kiaxi, which was inaugurated in February 2006. The US\$ 8 million contract was awarded to a Chinese company, and the construction took 15 months. Today the hospital accommodates 100 patients and offers speciality services in laryngology, dermatology, neurology, ophthalmology and physiotherapy. ${ }^{23}$ President Hu Jintao visited the premises in June 2006 during his state visit, and appraised it as a symbol of the growing friendship between China and Angola. ${ }^{24}$ The hospital also contains an antimalaria centre, which has set a precedent within FOCAC member states. ${ }^{25}$

Notwithstanding Angola's efforts to restore and increase the number of medical facilities across the country, its poignant dearth of medical doctors is of grave concern. According to former Minister of Health Anastácio Ruban Sicáto, of the 57,000 medical workers in the country less than 2000 of them are doctors. The overwhelming majority consists of nurses and technicians. ${ }^{26}$ This debilitates the public health system, and as a result many patients must receive treatment abroad through the Ministry's National Medical Association.

In 2008 Angola and China signed an agreement pertaining to the dispatching of Chinese medical doctors. However, the programme was postponed on account of inadequate housing for the doctors. New accommodation has since been arranged in Kilamba Kiaxi, where 20 houses have been built in the vicinity of Luanda's Central Hospital. Angola received 18 Chinese medical doctors during the second half of 2009. ${ }^{27}$ The Chinese provide new treatments in urology, acupuncture and cardiology.

\section{Education}

At independence in 1975, Angola launched an ambitious public education system, offering schooling free of charge from primary to tertiary level. However, the public education system soon came under strain as civil war erupted. With only brief interludes of peace the war continued until 2002, with the result that an entire generation of Angolans had only erratic access to formal education. Today, many adults are registered in evening classes either to complete secondary or tertiary studies. Private schools have dominated the education system since the mid-1990s, but still offer little assurance of a quality education.

The Angolan government is determined to restore its public education system. Chinese companies feature prominently in the restoration and construction of education facilities in Angola, many of which are also funded through the concessional loans provided by the Chinese government. This area of cooperation is managed by Angola's Ministry of Education.

In 2005 the Golden Nest Angola $\mathrm{Lda}^{28}$ received funding to build 11 schools: four junior schools in Luanda's districts of Cacuaco, Panguila and Viana; and six science and technology colleges in the city's Cacuaco, Cazenga, Panguila, Sambizanga and Viana districts and also in Lobito. Golden Nest spent US\$ 19.95 million renovating Malange's Agricultural College, which was inaugurated by President dos Santos in July $2007 .{ }^{29}$ That same year the company received a second round of funding to build five technical institutes and four secondary schools in Bengo, Benguela and Luanda. In accordance with FOCAC's Beijing Action Plan (2006), the Chinese government is 
funding the renovation of one primary school in Luanda, the construction of another primary school in Bengo and of two secondary schools in Benguela and Kwanza Sul respectively. $^{30}$

Sinohydro was contracted for a US\$ 69 million project to build four secondary schools over the period 2007-2008 (two schools in Huambo and another two in Huíla). The company also began working on a US\$ 93 million project in July 2007, building four colleges in Luanda, Bengo, Cabinda and Namibe; five management and administration institutes in Benguela, Namibe, Zaire and two in Luanda; and six secondary schools, two each in Luanda, Benguela and Namibe. ${ }^{31}$

Sino-Angolan cooperation in education also entails higher education, through Chinese government sponsored scholarships. Angola's scholarship programmes are managed by the National Institute for Scholarships (Instituto Nacional de Bolsas de Estudo - INABE). Angolan students prefer to study in Europe, the United States, Brazil and South Africa. However, according to INABE there is growing interest from students in China as well. The number of Chinese-granted scholarships has averaged at six annually for the past four years, except in 2008 when 15 students were admitted into the programme. ${ }^{32}$ Once in China the students' first year is spent at an intermediary institution, where they study Mandarin Chinese. In their second year the students are then assigned to different universities around the country to study their specialities.

\section{Agriculture and fisheries}

In 2008 Angola's agricultural sector contributed US\$ 10 billion to the economy, a mere $9.2 \%$ of the gross domestic product (GDP) ${ }^{33}$ Although production is low at the moment, Angola's is aiming high with plans to achieve food self-sufficiency by the year 2012. The Ministry of Agricultural and Rural Development (Ministério da Agricultura e Desenvolvimento Rural - MINADER) conducted a study in 2006 to determine which tools would be required to improve nutrition and establish food security. Various actors were consulted, including other ministries, UN agencies, the EU Commission, donors, non-governmental organisations (NGOs) and universities. The process led to the launch of the National Food and Nutritional Security Strategy (Estratégia Nacional de Segurança Alimentar e Nutricional — ENSAN) and its corresponding Action Plan (Plano de Acção de Segurança Alimentar e Nutricional PASAN) for the period 2009 to $2013 .^{34}$

In the same vein, Angola's Prime Minister Paulo Kassoma appealed to the country's academics and scientists in mid-2009 to assist with agrarian research that would help government guarantee the well-being of Angolan families. ${ }^{35}$ Angola would need to strengthen human resources, technical expertise and institutional capacity to bolster food production. To fast-track this process, multiple parties are being co-opted to assist the country's agricultural sector, including the Chinese government.

In August 2004 China and Angola signed a six-month procurement contract to the value of US\$ 22.36 million, for agricultural equipment, machines and tools for MINADER. The merchandise has been distributed to the Institute for Agricultural Development (Instituto de Desenvolvimento Agrário — IDA) and the National Company for Agricultural Mechanisation (Empresa Nacional de Mecanização Agrícola - MECANAGRO). Another procurement contract was signed by March 2005, valued at US\$ 32 million and was used to further stock MECANAGRO. ${ }^{36}$ 
In July 2005 MINADER contracted China’s Sinohydro for US\$ 54 million to set up irrigation systems in four regions: Caxito (Bengo), Gandgelas (Huíla), Luena (Moxico) and Waco-Kungo (Kwanza Sul). ${ }^{37}$ A year later Sinohydro completed another US\$ 5 million project that was also funded by the credit line from China. It built a hydroelectric dam in Gangelas and an irrigation channel in Chibia, which are situated some 20 kilometres south of Lubango in Huíla Province. Chibia's irrigation channel covers an area of 1400 hectares of arable land and the dam stores a volume of 3.5 million cubic meters of water. The Chibia municipality is a small farming community of just 133,000 inhabitants, with some 60 farming associations and cooperatives. There are plans underway to produce citrus fruits, maize, massango, massambala, leguminous plants and vegetables. ${ }^{38}$

China's commitment to assist African agricultural development is evident through the more than 200 cooperation programmes that have been rolled out in the sector since the 1960s, which include the dispatching of Chinese agricultural experts, agro-technology programmes and the construction of demonstration centres.

Chinese aid also extends into fisheries, cooperating with Angola's Ministry of Fisheries. The Ministry has a programme dubbed the 'Fishing Fleet Renewal' (renovação da frota de pesca), which is managed by the Fund for Assistance to the Fisheries and Industry and Agriculture (Fundo de Apoio ao Desenvolvimento à Pesca Artesanal - FADEPA) and Artisan Fishing and Aquaculture Development Institute (Instituto de Desenvolvimento da Pesca Artisanal - IPA). The objective of the programme is to distribute tools and resources throughout the country's fishing provinces: Bengo, Benguela, Cabinda, Luanda, Kwanza Sul and Zaire. The cooperative has set a target to distribute 3000 boats by 2010 to the maritime artisan fishing sector, which will effectively replace half of the existing stock. It was reported in February 2009 that FADEPA had received 440 vessels, of which China provided 250 and Spain provided $190 .{ }^{39}$

\section{Housing and sports facilities}

There is a high demand for new housing in Angola, where an estimated one-third of the country's population of just under 13 million $^{40}$ resides in the capital city and its periphery. This situation is a result of recent urbanisation and a legacy of massive migration that occurred during the civil war. To this day there remain great disparities in the occupant density of various parts of Angola.

For a city that was originally built for 500,000 people, today Luanda is home to over 5 million people. ${ }^{41}$ New residential areas such as Talatona, Benfica and Camama have in recent years drawn many families out of the inner city, but much more decentralisation is required. Angola launched the National Urbanisation and Housing Programme on 13 April 2009, which aims to build one million houses over the next four years in key areas. A few days after launching the programme, Angolan Minister of Public Works, Higino Carneiro, led a delegation to China to reinforce bilateral cooperation, ${ }^{42}$ an indication of Angola's continued confidence in Chinese assistance with development.

In early May 2009, it was reported that Pan-China Construction Ltd, would develop the new Dundo City, in the north-east of Lunda Norte Province. ${ }^{43}$ The city will have nearly 200,000 new residences, over a four square-kilometre area, to meet the growing demand for housing in the province, especially now that the area is attracting much activity surrounding the construction of the new 12.8 megawatt 
hydroelectric dam in the province. Included in the project are plans for the Chinese company to build schools, clinics and office buildings for Dundo.

China Nantong Holding Corporation was commissioned to complete the Funda Residential Housing Project for the Ministry of Defence, valued at US\$ 300 million. The construction on this three-phase project began in November 2008. The residence covers an area of 30 hectares, on which 2,000 apartments and several hundred villas will be built. This is the largest housing project undertaken yet by the country's Ministry of Defence. The Funda military compound will contain pre-primary, primary and middle schools, shops, swimming pools, health centres, sport facilities, street gardens and greeneries. ${ }^{44}$ The new residential zone will house military officers and their immediate families.

Chinese companies have also been involved in the construction of new sports facilities, namely the renowned soccer stadiums that hosted the Cup of African Nations (CAN) in January 2010. Shanghai Urban Construction Group (SUCG CN) and Sinohydro built four new soccer stadiums in Benguela, Cabinda, Luanda and Lubango. Luanda's stadium is situated in Camama district, some 20 kilometres away from the inner city. The stadium is the biggest of all four, with a capacity for 50,000 spectators. SUCG $\mathrm{CN}$ had 1500 people working on the construction team to complete the work on time for the opening and closing ceremonies of CAN $2010 .^{45}$ The stadium in Benguela has a capacity for 35,000 seats, while the remaining two stadiums each seat 20,000 spectators. ${ }^{46}$

\section{Transport infrastructure}

The Ango-Ferro 2000 project involves the rehabilitation of 3100 kilometres of railway, 8000 kilometres of extensions, 36 bridges, and rehabilitation and construction of 100 stations and 150 new substations. Angola has contracted the services of China Railway 20 (China Ferrovia 20, CR-20) on what may be the single largest infrastructure project that has been awarded to a Chinese company in Angola.

As displayed in Figure 1, the project involves three railway lines: the Luanda railway route from Luanda to Malange; the Benguela railway route from Benguela to Huambo to Luena to Luau; and the Moçâmedes railway route from Namibe (formerly Moçâmedes) to Lubango to Menongue.

The Luanda railway stretches over 450 kilometres and was completed in 2008, then formally handed over to the Angolan government in April 2009. Within Luanda province, the train has become especially popular for commuters between the city and Viana. Merchants from Malange also use the carriers as mobile markets, selling goods at the various stops along the route.

The Benguela railway is the longest of the three. It stretches over 1343 kilometres of rail, cutting across four provinces. The railway will serve to link Africa's east coast to the west coast, through linkages in the Democratic Republic of Congo, Zambia and Tanzania and/or Mozambique. Work on the Benguela railway began in June 2005 and only 30\% of the track had been laid as of March 2009. The Moçâmedes railway is the third line. Its rehabilitation started in 2006; it is expected to be completed by 2010 . This line stretches over 950 kilometres. $^{47}$

Angola has also involved Chinese companies by restoring and developing over 10,400 kilometres of the country's road networks. Table 2 cites some of Angola's prominent transport infrastructure projects reported in the media that involved Chinese funding and/or enterprises. 


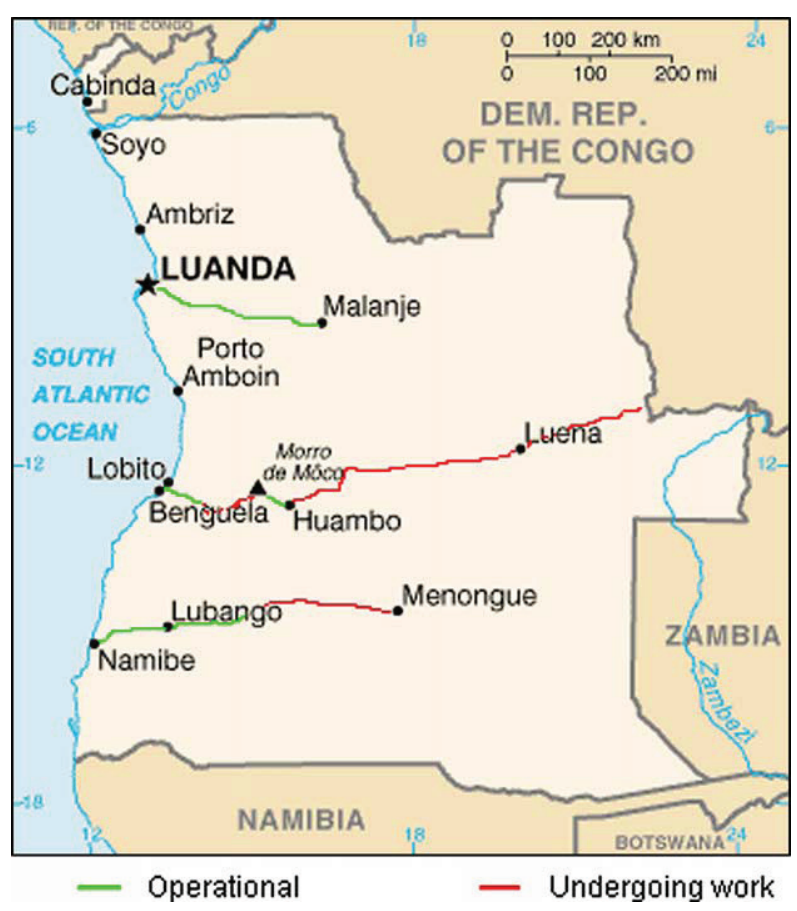

Figure 1. Ango Ferro

Source: US Central Intelligence Agency website < http://www.cia.gov/library/publications/ the-world-factbook/geos/ao.html >, with author illustrations depicting railways, 2010 .

\section{Utilities}

In January 2009, the China National Machinery and Equipment Import and Export Corporation (CMEC/CMIC) signed a US\$ 298 million contract for the 'Electrification Project for Southern Suburbs of Luanda in Angola' ${ }^{48}$ It is building

Table 2. List of prominent Sino-Angola road projects (2007-2009)

\begin{tabular}{lcccc}
\hline Project & $\begin{array}{c}\text { US\$ } \\
\text { Million }\end{array}$ & $\begin{array}{c}\text { Year } \\
\text { awarded }\end{array}$ & Creditor & Contractor \\
\hline $\begin{array}{l}\text { Road links in Cabinda and Zaire } \\
\text { provinces }\end{array}$ & 3 & 2007 & China Exim Bank & - \\
$\begin{array}{l}\text { Cunene Bridge } \\
\begin{array}{l}\text { City streets of Caxito (Bengo), } \\
\text { Uige and Negage (Uige) }\end{array}\end{array}$ & 30 & 2007 & China Exim Bank & - \\
$\begin{array}{l}\text { Road, electricity and water } \\
\text { systems }\end{array}$ & 136 & 2008 & China Exim Bank & - \\
$\begin{array}{l}\text { National roads: Uíge/Quinzala/ } \\
\quad \begin{array}{l}\text { Damba/Maquela do Zombo/ } \\
\text { Negage to Bungo }\end{array}\end{array}$ & 79.6 & 2008 & China Exim Bank & - \\
\hline
\end{tabular}

Sources: ${ }^{a}$ Corkin L AERC Scoping Exercise on China-Africa Relations: The Case of Angola. Nairobi: The African Economic Research Consortium (AERC), 2008. ${ }^{\mathrm{b}}$ China Digital Times 'China expands credit line to Angola', 4 July 2008, < http://chinadigitaltimes.net/china/angola/ >. 'MacauHub 'Chinese company build roads in Uíge province', 3 June 2009, <http://www.macauhub.com.mo/en/news.php?ID =7498 > dAgência Angola Press 'Public work minister proceeds work in Uige Province', 3 June 2009, <http:// www.portalangop.co.ao/motix/en_us/noticias/sociedade/2009/5/23/Public-Work-minister-proceeds-WorkUige-Province, 7at84c7e-983c-4831-8f80-23718870f0f6.html > . 
transmission lines, substations and power distribution facilities in the Luanda municipal district. The project will boost the capital city's electricity supply substantially, considering the city currently suffers from chronic power outages that in certain areas occur up to four times a day and in some areas last for periods longer than 48 hours at a time. CMEC has been actively involved in Angola's electrification process for several years already, during which time it has already completed the installation of transmission lines and the rehabilitation of the grid system in the greater Luanda area. ${ }^{49}$

\section{Human resource development}

Cooperation in human resources development involves the training of Angolans in China. The Angolan candidates attend a series of workshops and lectures for periods of between two weeks and two months depending on the specialty. Training programmes are available in various fields, from trade, information technology, agriculture, medical botany, distance learning, vocational education, nursery education, economic management, and military administration to journalism, culture and tourism, and even low-interest loan provision. Among the institutions that specialise in African studies are Beijing University and Zhejiang Normal University. Several technical colleges and universities are co-opted for their specialties and scientific disciplines. ${ }^{50}$

In April 2007, the Chinese government sent a MOFCOM delegation to Angola to negotiate opportunities for human resources development. The delegation reportedly met with 15 of Angola's key ministries to discuss research activities, training topics, training methods, and participant organisations. ${ }^{51}$ Following the visit approximately 200 Angolan officials and professionals received training in China during the course of 2007 and 2008, primarily in agriculture and industry. ${ }^{52}$

On the other hand, there are also questions about the quality and extent of the human resources development taking place in Angola. Studies performed reveal mixed findings. ${ }^{53}$ In the construction sector, for instance, critics argue that the number and prominence of Chinese workers inhibit skills development. First, they claim that too few Angolans are hired. Second, even those who are able to join the workforce claim they perform only menial tasks. These are both valid concerns since Angola's investment law $^{54}$ reads that specific investors (local and foreign) must 'promote the training of national labour and the progressive taking over of management and other posts of responsibility by Angolan nationals'. Training Angolans on projects contracted to Chinese companies is a reasonable goal. Expecting Chinese firms to hand over management of these projects to Angolans is perhaps less so. In any case, although these companies are expected to follow the general laws and regulations of Angola, they are contracted on aid projects and do not register with the National Agency for Private Investment (Agência Nacional de Investimento Privado - ANIP) as investors. Due to the strategic cooperation for development, they are therefore not required to supply 'Angolanisation'55 plans. In response to the criticism about minimal training, a local politician argued that the public has unrealistic expectations of China. Acknowledging the language barrier with Chinese firms, the respondent remarked that there are many other international construction and engineering firms working in Angola from which Angolans could learn and develop new skills. ${ }^{56}$ 


\section{The Chinese credit line: the risks for Angola}

There are growing concerns over the risks for African economies in initiating another round of high indebtedness via their aid from China, most of which comes in the form of concessional loans.

This concern is based in history. Commonly, debt service capacity is managed by the state to ensure that a nation's indebtedness does not debilitate it economically. Unfortunately many a developing country's mismanagement of debt, coupled with increased loans and in some cases unfavourable market conditions, has in the past created a catastrophic financial predicament for which, eventually, debt relief was sought as a plausible solution.

Angola, however, has made positive steps towards reducing its external debt. In late 2006 and early 2007, Luanda settled its outstanding debt with the members of the Paris Club amounting to US\$ 2.3 billion in interest and principle. Angola also signed an agreement with the Paris $\mathrm{Club}^{57}$ on new terms and conditions for the payment of US\$ 1.8 billion in interest on late payments accumulated during its years of civil war. ${ }^{58}$

Angola's external debt has gradually decreased over the years from $39.5 \%$ of GDP in 2005 to $20.7 \%$ in 2006 and to $15.6 \%$ in $2007 .{ }^{59}$ The country is now in a position to meet the schedule of its current external debt service payments. According to the World Bank, Angola's cumulative external debt is an estimated US\$ 11 billion. ${ }^{60}$ This appears trivial when considering that the country's GDP in 2008 was an estimated US\$ 110.3 billion. However, one must recognise that the economy is almost entirely dependent on mineral exports, namely of oil and diamonds. As such, economists are concerned about Angola's capability to service its external debt and China's role as an 'enabler' in furthering its indebtedness. Furthermore, the past record of easing conditions for debt relief may have a perverse effect on borrowing, as countries are tempted to borrow more money in anticipation of debt forgiveness. ${ }^{61}$ Angola must avoid this trap.

Chinese authorities consider that $90 \%$ of its aid in kind and all zero interest loans to African countries will be written off over time. ${ }^{62}$ This coincides with Hu Jintao's decision, announced as China's $5^{\text {th }}$ policy measure at the 2006 FOCAC summit, to 'cancel debt in the form of all the interest-free government loans that matured at the end of 2005' for all African HIPCs and LDCs that have diplomatic relations with China. Furthermore, China has indicated plans to cancel additional debt for interestfree loans to LDCs that matured in $2008 .{ }^{63}$

In this vein, Angola and China signed an agreement in 2007, from which China cancelled RMB 50 million (approximately US\$ 7 million) of debt owned by the Angolan government. ${ }^{64}$ Between that agreement and subsequent minor amounts of debt relief, the Chinese Minister of Commerce Chen Yuan announced in January 2009 that China's debt relief towards Angola had reached RMB 67.38 million, or approximately US\$ 10 million. ${ }^{65}$

The growing concern over Angola's mounting indebtedness must be weighed up against Angola's enormous needs to support its reconstruction and development. At the same time, China's policy of non-interference in domestic governance issues and condition-free loans are also of concern: there are considerable risks involved with such unlimited credit. Might these policies be enabling factors that reinforce Angola's poor record of governance and the contention over corruption? ${ }^{66}$ There is certainly an opaque nature to the bilateral relations, but one feature remains clear: 
both parties acknowledge and respect the distinguishing limitations of their political and economic diplomacy.

\section{Policy recommendations}

The policy recommendations provided below aim to support the national interests of Angola with regard to aid specifically, bearing in mind the country's development agenda and its strategic cooperation with China. In this light, Angola should consider the following steps.

\section{Sustain healthcare and empower Angola with medical and pharmaceutical expertise}

Angola is expanding its anti-malaria campaign by increasing its scope and improving its consistency. The donation of anti-malaria medication is certainly a valuable programme, but it is unsustainable. Malaria is a tropical disease, and until there is a vaccine it will remain an enduring one in Angola. Although the provision of an antimalaria centre in Luanda's Central Hospital is commendable, Angola could guide China's cooperation towards empowering its professionals with medical and pharmaceutical expertise in order to build capacity and promote technology transfer. Therefore, instead of continual donations every year, the Angolan government may consider lobbying for the domestic manufacturing of the anti-malaria drugs to meet demand.

Likewise, the dispatching of Chinese medical doctors to Angola is a positive initiative that enables mutual learning amongst medical practitioners. Patients benefit from alternative Chinese medicines and techniques, and by having additional medical doctors available. However, the language barrier is an impediment and affects the consultation process. The doctors could be encouraged to learn Portuguese (medical terms and casual conversation), particularly those who may not be accompanied by an interpreter, in order to ease their integration and communication. Upon their arrival they could do an intense two-week language immersion course, followed by subsequent weekly lessons in the months thereafter.

\section{Refine the infrastructure development agreements}

The barter deals may be considered a 'win-win' for both parties, but they have created an environment where Angola is on the receiving end of enormous amounts of 'Chinese' services in infrastructure development. A contentious subject of discussion is that China's current model for infrastructure development in Angola provides minimal employment opportunities for locals and does very little to alleviate the country's skills shortage. The immediate results of the current arrangement are rewarding, but present inevitable risks in the long-run for the maintenance of the infrastructure. It is therefore necessary to refine the terms of the agreements for infrastructure development projects, in order to foster improved employment equity, skills development and technology transfer.

\section{Cultivate economical agricultural practices}

Approximately $85 \%$ of Angola's labour force is dependent on the agricultural sector to sustain their livelihoods. By consequence, any disregard for these farmers or 
state-orchestrated substitution of subsistence farming by commercial farming will have a devastating effect on more than 6 million people. Once again, Angola could learn from China's experience in this sector. Chinese agriculture is comprised of some 200 million small farmers, who each cultivate produce on perhaps less than half a hectare of land. The effectiveness of Chinese agricultural aid programmes in Africa remains questionable, as the results are yet to be determined in the various countries. However, the onus rests with MINADER to strategically co-opt Chinese aid in a manner that will efficiently maximise and sustain agricultural productivity. Subsistence farmers could be empowered with new skills and technology. All Chinese sponsored tools and programmes could be adapted to meet the requirements and satisfaction of the local communities. A focus could be placed on production for one's immediate market, before expanding into provincial, national and international markets. Preferential access to the Chinese market is futile for the moment, as food security and self-sufficiency are the priority. As such, Angola needs to re-establish its rural-urban trade, improve its supply chain networks and refine logistics. It is by investing in rural livelihoods that rural life will become sustainable.

\section{Industrialise the fishing sector}

The increasing productivity of the fishing sector provides an opportunity to formalise the sector through industrialisation, involving the processing and packaging of marine products. Intermediary auctions may be set up to link artisanal fishermen with companies. Fishing alone gives the illusion of productivity, but it is a risky and an unsustainable activity. Catches may be erratic, due to environmental reasons and/or poor technique. In order to valorise the sector, there needs to be improved systems and value added to the merchandise. Processing and packaging the marine products will create employment, introduce new skills, enable technology transfer and give rise to export opportunities.

\section{Institute quality control of infrastructure projects}

The quality control fiscalização (monitoring and oversight) that is carried out on construction contracts in Angola has a patchy track record. While some contractors attest to the stringency of the process, it has been described by others as a rubberstamp process that pays lip-service to its function of auditing and overseeing the successful execution of the project. ${ }^{67}$ China is not the only country financing infrastructure projects in Angola. Also, Chinese companies are not the only companies in Angola who have been accused of inadequate workmanship or the flouting of labour and environmental standards. Independent engineering contractors to oversee projects are of vital importance to ensuring quality control on services delivered. Where independent contractors have been employed in the past in Angola, the results have been highly successful. ${ }^{68}$ This process should thus be encouraged on projects contracted to Chinese companies as well.

Part of due diligence is the promotion of safety and security, which needs urgent attention in Angola, on the roads and railways particularly. Pedestrian crossings and bridges need to be installed in key points, as well as barricades along roads. Similarly, the crossings over the railway lines remain hazardous and in need of suitable precautionary measures. 


\section{Capitalise on Chinese sponsored scholarships}

Angola could review the management of the Chinese government-sponsored scholarships, from start to finish. INABE could lobby for specialisations that support Angola's strategic plan, such as agronomy, petroleum engineering, civil engineering and business management. Upon completion of studies, the graduates who return to Angola may then be channelled into strategic positions where their newly-acquired professional expertise could be used but also where their proficiency in Mandarin Chinese may be leveraged.

\section{Conclusion}

Chinese development assistance to Angola has increased significantly since the end of the civil war. Both parties have been able to secure their national interests using very strategic and opportune mechanisms of diplomacy. China has emerged in the new millennium as an economic force to be reckoned with, now assuming the position of the world's second largest economy. Its own experience has prompted a paradigm shift in development theory, which has penetrated its foreign policy towards other developing countries and particularly those in Africa. China's diplomatic efforts in FOCAC and bilaterally with African countries demonstrate a new feature of Chinese policy, as development partner.

China is a significant new player in the donor community; it is challenging the parameters of aid with its own preconceived ideas and mechanisms of disbursing funds. The OECD players use aid to relieve poverty and promote development, but also to induce good governance. China seemingly imposes no political conditionalities, which the traditional donors believe undermines their efforts. This is especially contentious because up until now the effectiveness of aid has come under question, yet China's efforts appear to be popular and are seemingly successful in Angola.

The emergence of the 'Angola Mode' has set a precedent, both in development theory and in the international donor community. The exchange of resources for services is an innovative model to fast-track infrastructural development. The mechanisms used to disburse the funds also lower the risk of financial mismanagement and the misappropriation of capital.

The thematic focus of Chinese aid to Angola is varied. Infrastructure development is the main component, consisting of projects in utilities, transportation and other public works. Chinese companies have also been contracted to build schools and medical centres. Chinese medical doctors are dispatched and scholarships are awarded. With Angola's construction sector experiencing a major boom, the projects could be suitable for employment creation. However, the import of Chinese services also includes a major expatriate labour force. Concerns have been raised over the sustainability of this model and the impediment it causes for domestic skills development and technology transfer.

The credit line made available to Angola by the PRC and other actors (namely CIF) have certainly increased Angola's debt. However, as long as Angola is borrowing funds the country's debt would increase accordingly irrespective of the source. The real concern is whether China is lending responsibly.

Angola is working to address many political, economic and social challenges at a national level, and the aid efforts of its partners should be synchronised with this 
agenda. China-Angola aid relations appear to be benefiting the country, as the output is tangible and extremely visible around the country, from newly-erected schools and hospitals and homes to new sports facilities. However, only time will reveal the long-standing impact of China-Angola aid relations. It is imperative, in light of that fact, to place a stronger emphasis on human resource development to ensure sustainability.

\section{Acknowledgements}

The author wishes to acknowledge the African Economic Research Consortium (AERC) and the Rockefeller Foundation for generously facilitating this research, as well as thank Dr Liu Haifang and Lucy Corkin for their mentorship.

\section{Note on contributor}

Carine Kiala holds a Masters degree in International Relations from the University of Pretoria.

\section{Notes}

1. A wide range of data sources was used, comprising personal interviews, primary sources, official documentation, policy documents, theoretical literature, as well as critiques and discussion papers from the media. Field research was performed in Luanda between 2 and 13 March 2009, then in Beijing between 22 April and 2 May 2009.

2. Brautigam D 'China's Challenge to the International Aid Architecture', World Politics Review, 1, 4, June 2009, pp. 1-10.

3. References to current programmes under Sino-Angolan military cooperation are cited in: Agência Angola Press 'Angola, China strengthen military cooperation', 26 May 2010, $<$ http://www.portalangop.co.ao/motix/en_us/noticias/politica/2010/4/21/Angola-Chinastrengthen-military-cooperation,2805b35d-2949-4734-8712-f8d390d2337f.html > .

People's Daily Online 'China, Angola vow to advance military ties', 21 July 2010, $<$ http://english.peopledaily.com.cn/90001/90776/90883/7074548.html >.

4. Interview, Professor Li Anshan, Peking University, 23 April 2009, Beijing.

5. The 'One China' policy infers to the People's Republic of China's position on Taiwan and its contested sovereignty. In foreign affairs, countries that seek diplomatic relations with the PRC must denounce official relations with Taiwan and recognise it as a territory of the PRC.

6. Much of FOCAC's 2006 Beijing Action Plan is drawn from the whitepaper of China's African Policy that was released in January 2006.

7. Interview, Qiu Bohua, FOCAC Ambassador, Ministry of Foreign Affairs, 24 April 2009, Beijing.

8. Varied studies have been conducted, including: Sachs JD \& AW Warner 'Sources of slow growth in African economies', Journal of African Economies, 6, 3, 1997, pp. 335-76. Collier P \& G Gunning 'Why has Africa grown slowly?', Journal of Economic Perspectives, 13, 3, 1999, pp. 3-22.

9. Reisen H Is China Actually Helping Improve Debt Sustainability in Africa. Paris: OECD, 2007.

10. World Bank 'China Eximbank and World Bank come together to sign cooperation memo', news release: 2007/EAP/376, 21 May 2007, accessed 12 August 2009, <http:// web.worldbank.org/WBSITE/EXTERNAL/NEWS/0,, contentMDK:21342649 menuPK: $51062075 \sim$ pagePK:34370 piPK:34424 theSitePK:4607,00.html >.

11. AfDB AfDB and China Development Bank sign a Memorandum of UnderstandingPartnership will Focus on Africa's Economic Development Activities, 1 September 2008, 
accessed 17 August 2009, < http://www.afdb.org/en/news-events/article/afdb-and-chinadevelopment-bank-sign-a-memorandum-of-understanding-partnership-will-focus-onafricas-economic-development-activities-2006/ > .

12. The New Atlantis, 'Power hungry China: The international consequences of China's quest for energy', 4, 2004, < http://www.thenewatlantis.com/publications/power-hungrychina $>$.

13. Onuoha $G$ 'Energy and security in the Gulf of Guinea: A Nigerian perspective', South African Journal of International Affairs, 16, 2, p. 247.

14. Emmanuel VW 'Chinese investments in Angola', in Baah AY \& H Janch Chinese Investments in Africa: A Labour Perspective. Windhoek: African Labour Research Network, 2009, p. 369.

15. Campos I \& A Vines Angola and China: A Pragmatic Partnership. London: Chatham House, 2008.

16. Corkin L AERC Scoping Exercise on China-Africa Relations: The Case of Angola. Nairobi: The African Economic Research Consortium (AERC), 2008.

17. MOFCOM Minister of Commerce Chen Deming Meets with Angolan Prime Minister Kassoma and Holds Separate Talks with Angolan Ministers of Finance and Trade, 2009, accessed 28 May 2009, <http://chendeming2.mofcom.gov.cn/aarticle/activity/200901/ 20090106017698.html >.

18. Calculated from data from $<$ http://ipsnews.net/news.asp?idnews $=36612>$.

19. FightingMalaria Country Profile/President's Malaria Initiative (PMI): Angola, 2010, $<$ http://www.fightingmalaria.gov/countries/profiles/angola_profile.pdf $>$.

20. AllAfrica 'Angola: Health minister says war hindered HIV/AIDS spread in nation', 18 March 2010, <http://allafrica.com/stories/201003190964.html >.

21. Ministry of Finance Obras do Governo - Saúde, 2009, < http://www.minfin.gv.ao/docs/ dspSaude.htm $>$.

22. Ministry of Finance Lihna de Crédito com o Exim Bank da China: Projectos Concluído. Luanda: Gabinete de Apoio Técnico, 2007.

23. MacauHub Chinese Builder COVEC Interested in State-Private Partnerships in Angola, 2006, < http://www.macauhub.com.mo/en/news.php?ID =832 > . Agência Angola Pres 'Luanda governor fires hospital directors', < http://www.portalangop.co.ao/motix/en_us/ noticias/saude/Luandas-governor-fires-Hospitals-directors,f6ca083f-6126-44d9-b68f-1ee34 160c9a1.html > .

24. Interview, Chinese Economic and Counsellor Office, 9 March 2009, Luanda.

25. To assist in combating malaria, which is a pandemic across the continent, Beijing donates anti-malaria medication to African countries. Angola's Ministry of Health received some RMB 2 million worth of medication (approximately US\$ 300,000) on 9 April 2009. Such provisions increase the availability of the medication, but its distribution remains a challenge. Source: Author interview with Chinese Ambassador to Angola, 10 March 2009, Luanda.

26. Angola Xyami 'Entrevista a Anastácio Rubén Sicato Ministro da Saúde do Governo do Angola (GURN)', 22 April $2008<$ http://www.angolaxyami.com/Personagens-Entrevistaa-Anastacio-Ruben-Sicato-Ministro-da-Saude-do-Governo-de-Angola-GURN.html > (accessed 15 November 2010).

27. All Africa 'Angola: Luanda Central Hospital Reinforces Medical Staff' 14 April 2009, $<$ http://allafrica.com/stories/200904150691.html > (accessed 15 November 2010).

28. Golden Nest Angola Lda, a Chinese company by origin, has been operating in Angola since 2001.

29. Interview, Golden Nest Lda, 8 May 2009, Luanda.

30. Interview, Ministry of Foreign Affairs and Cooperation - Asia and Oceania, 5 March 2009, Luanda.

31. Angolan Ministry of Finance Obras do Governo - Educação, 2009, < http://www. minfin.gv.ao/docs/dspEducacao.htm $>$.

32. Interview, Instituto Nacional de Bolsas de Estado, 10 March 2009, Luanda.

33. CIA World Factbook Angola, 2009, accessed 2 June $2009<$ https://www.cia.gov/library/ publications/the-world-factbook/geos/ao.html > . 
34. Interview, Ministry of Agriculture and Rural Development, 12 March 2009, Luanda.

35. Agência Angola Press 'Premier wants food production research', 30 April 2009, $<$ http://www.portalangop.co.ao/motix/en_us/noticias/economia/Premier-wants-food-prod uction-research,2f1bec58-fc80-475c-b187-f9990198d44f.html > .

36. Ministry of Finance Lihna de Crédito com o Exim Bank da China: Projectos Concluído. Luanda: Gabinete de Apoio Técnico, 2007. A local informant suggested that the distribution of the machinery needed to be reviewed, commenting that no training is offered for mechanics in maintenance. As a result, many new tractors that should have a 10 -year lifeline are already in disrepair.

37. Angolan Ministry of Finance Obras do Governo - Agricultura e Pescas, 2009, < http:// www.minfin.gv.ao/docs/dspProjIrrigaAgri.htm $>$.

38. MacauHub 'Angola: Chinese company builds Gangelas dam in Huila province', 2008, $<$ http://www.macauhub.com.mo/en/news.php?ID =5410 > .

39. Agência Angola Press 'Angola gets over 400 new fishing boats', 17 February 2009, $<$ http://www.portalangop.co.ao/motix/en_us/noticias/economia/Angola-gets-over-400new-fishing-boats,01c86a34-1e35-4e9a-bdd9-8cc5ec9e77d8.html > .

40. July 2010 estimate, from CIA World Factbook, 'Angola', accessed 14 October 2010, $<$ https://www.cia.gov/library/publications/the-world-factbook/geos/ao.html >.

41. Interview, Centro de Estudos Estrategicos de Angola (CEEA — Strategic Studies Centre of Angola), March 2009, Luanda.

42. Agência Angola Press 'Angolan delegation ends visit to China', 19 April 2009, < http:// www.portalangop.co.ao/motix/en-us/noticias/economia/2009/3/16/Angolan-delegationends-visit-China,650ea4c1-2633-4467-896d-5d75497b4c4f.html > .

43. 'China's involvement in Angola: Mutually beneficial commercial pragmatism' The China Monitor, a publication of The Centre for Chinese Studies, Faculty of Arts and Social Sciences, Stellenbosch University, 38, March 2009, p. 8, <http://www.ccs.org.za/wpcontent/uploads/2009/05/china-monitor-march-2009.pdf $>$ (accessed 15 November 2010).

44. China View 'China starts construction of housing project in Angola's capital', 2008, $<$ http://news.xinhuanet.com/english/2008-11/12/content_10343689.htm > .

45. Agência Angola Press 'Luanda's stadiums construction going as planned', 28 January 2009, accessed 10 June 2009, <http://www.portalangop.co.ao/motix/en_us/noticias/ desporto/Luanda-stadiums-construction-going-,planned,a30a4536-0142-4fd4-86f9-69995 816a72a.html >.

46. AllAfrica 'MO Happy with construction work of Luanda stadium', 10 June 2009, accessed 2 July 2009, < http://allafrica.com/stories/200906100719.html > .

47. Ministry of Transport Ministro dos Transportes visita infra-estruturas na Huila, 22 July 2008, <http://www.angola-portal.ao/MINTRANS/NoticiaD.aspx?Codigo $=4496>$.

48. 'CMEC successfully signed electrification project for southern suburbs of Luanda in Angola', Sinomach 2009.

49. Interview, CMEC, 9 March 2009, Luanda.

50. Liu Haifang, 'China-Africa relations through the prism of culture - the dynamics of China's cultural diplomacy with Africa', China Actuelle, Journal of Current Chinese Affairs, 38, 3, 2008, pp. 9-46.

51. MOFCOM Angola. 28 April 2007, accessed 6 July 2009, <http://ao.mofcom.gov.cn/ aarticle/sqfb/200704/20070404624639.html > . Article in Chinese.

52. Interview, Chinese Economic and Counsellor Office, 9 March 2009, Luanda.

53. See Emmanuel VW 'Chinese investments in Angola', in Baah AY \& H Janch Chinese Investments in Africa: A Labour Perspective. Windhoek: African Labour Research Network, 2009.

54. Refer to Article 18 (b) of the Basic Private Investment Law.

55. According to Angola's private investment law, foreign investors are required to provide an Angolanisation plan that stipulates their strategy for human resources, training, skills development and the replacement of expatriate staff with competent Angolan citizens over a set period of time.

56. For instance, there are three very prominent Portuguese firms in Angola currently working on contracts of similar magnitude as the Chinese enterprises, namely Teixeira Duarte, Soares da Costa and Motal Engil. 
57. The Paris Club consists of 19 members: Austria; Belgium; Canada; Denmark; Finland; France; Germany; Ireland; Italy; Japan; Netherlands; Norway; Russia; Spain; Sweden; Switzerland; the UK; and the USA.

58. AfDB/OECD African Economic Outlook: Angola, 2008, p. 129.

59. AfDB/OECD African Economic Outlook: Angola, 2008, p. 129.

60. World Bank Angola: Key Development Data \& Statistics. 2007, accessed 20 August 2009, $<$ http://web.worldbank.org/WBSITE/EXTERNAL/DATASTATISTICS/0,,contentMDK: $20535285 \sim$ menuPK:1192694 pagePK:64133150 piPK:64133175 theSitePK:239419, $00 . \mathrm{html}>$.

61. Easterly W' How did heavily indebted poor countries become heavily indebted? Reviewing two decades of debt relief', World Development, 30, 10, 2002, pp. 1677-696.

62. Reisen H Is China Actually Helping Improve Debt Sustainability in Africa. Paris: OECD, 2007.

63. Interview, Qiu Bohua, FOCAC Ambassador, Ministry of Foreign Affairs, 24 April 2009, Beijing.

64. ForumChinaplp. 2009, accessed 25 May 2009, <http://www.forumchinaplp.org.mo/zh/ notice.asp?a = 20080111_01 > .

65. China Daily 'Angola China's largest African trade partner' < http://www.chinadaily. com.cn/china/2009-01/19/content-740791.html > (accessed 19 January 2009).

66. For discussion of these issues, see for instance 'Good governance in Angola: Parliamentary accountability and control', Chr Michelson Institute, accessed 14 October 2009, http://www.cmi.no/research/project/?386 = good-governance-in-angola, and De Morais RM 'Angola: The presidency - epicentre of corruption', allafrica.com, 5 August 2010, accessed 14 October 2010, http://allafrica.com/stories/201008060882. html; and Campos I \& A Vines, 'Angola and China: A pragmatic relationship', Working Paper presented at a CSIS conference, 'Prospects for Improving US-China-Africa Cooperation', 5 December 2007.

67. Burke C, L Corkin \& L Tay China's Engagement of Africa: Preliminary Scoping of African case studies: A Scoping Exercise Evaluating China's Engagement of Six African Case Studies, prepared for the Rockefeller Foundation. Stellenbosch: Centre for Chinese Studies, 2007, p. 34.

68. Ibid., p. 34 . 